\title{
The TPP and East Asian Economic Integration: From the Japan-China-ROK perspective
}

\author{
Tomoyoshi Nakajima*
}

\begin{abstract}
This paper examines the influence Japan's participation in the TPP negotiations will have on the course of subsequent East Asian economic integration, and mainly from the perspective of the three Northeast Asian countries of Japan, China and the ROK. In the first half, as a premise thereto, we first bring together the development of the FTA policies of China, the ROK and Japan, and then the connections with East Asian economic integration.
\end{abstract}

Keywords: TPP, East Asian Economic Integration, China, Japan, ROK

JEL classification numbers: F01, F15, F53

Submission Date: 17/10/2012 Revision Date: 14/12/2012 Acceptance Date: 24/12/2012

* Tomoyoshi Nakajima, Senior Research Fellow, Economic Research Institute for Northeast Asia (ERINA), 13th Floor, Bandaijima Building, Bandaijima 5-1, Chuo-ku, Niigata City, 950-0078, Japan Tel: 81-25-290-5545, Fax: 81-25-249-7550, E-mail: nakajima.tomoyoshi.20@erina.or.jp 


\section{INTRODUCTION}

From the 1990s on, the global economy has been amid major moves to regional economic integration, including the realization of economic integration by the EU in Europe, and the establishment of NAFTA in North America. Amidst all this, in East Asia also, the other pole of the global economy, institutional economic integration is being sought after, against the backdrop of the increasing closeness of economic relations called a de facto economic integration.

Looking at the institutional aspects of East Asian economic integration, in Southeast Asia the institutional framework of trade liberalization called the ASEAN Free Trade Area (AFTA) has already come into effect, and in addition the discussion has been moved forward in a format with ASEAN at the core for the concepts of economic integration covering the entire area of East Asia, such as ASEAN +32 ) and ASEAN+6.3) Meanwhile, in Northeast Asia there are China and Japan, which are next behind the United States in economic size, in addition Japan and the ROK are at a level classified as developed in per capita income terms, and moreover the degree that they are dependent on international trade with other countries is high. These, generally, are conditions which advance intraregional economic integration, yet in reality institutional integration in Northeast Asia is lagging greatly behind that in Southeast Asia

Furthermore, in recent years, as the US response to East Asian institutional economic integration, new frameworks for economic integration have been indicated. As a medium-to-long-term vision a Free Trade Area of the Asia-Pacific (FTAAP), an FTA covering APEC in its entirety, has been advocated, and additionally the negotiations for the Trans-Pacific Partnership Agreement (TPP) that have been designated as its forerunner version by a limited number of starter countries have been steadily moved forward, and a situation has emerged where the number of countries participating in the negotiations has also expanded.

2) A framework for economic integration by a total of 13 countries: the 10 ASEAN nations, Japan, China, and the ROK. The ASEAN+3 Summit Meeting has been held since 1997. They have realized several economic cooperation measures, such as the Chiang Mai Initiative, a currency swap arrangement to stave off a currency crisis. As for an FTA concept within the region, there is an EAFTA (East Asia Free Trade Agreement), and after joint study it was agreed at the 2009 summit to have intergovernmental discussion thereon.

3) A framework for economic integration by a total of 16 countries: the 10 ASEAN nations, Japan, China, the ROK, India, Australia, and New Zealand. The East Asia Summit (EAS) has been held from 2005. As for an FTA concept within the region, there is a CEPEA (Comprehensive Economic Partnership in East Asia), and after joint study it was agreed at the 2009 EAS to have intergovernmental discussion thereon. Regarding the EAS, however, it was expanded with the addition of the United States and Russia as new official members from 2011. 
This paper examines the influence Japan's participation in the TPP negotiations will have on the course of subsequent East Asian economic integration, and mainly from the perspective of the three Northeast Asian countries of Japan, China and the ROK. In the first half, as a premise thereto, we first bring together the development of the FTA policies of China, the ROK and Japan, and then the connections with East Asian economic integration.

\section{CHINA'S FTA POLICY}

China's conclusion of FTAs began in earnest following its 2001 WTO accession. In this section, taking up the key ones from among China's FTAs to date, we analyze the background to their establishment, from there derive the distinctive features of China's FTA policy, and then look toward the direction of China's FTA policy in the future.

\subsection{Analysis of FTA Case Examples}

The situation for China's conclusion of FTAs is as shown in Table 1. Currently ten agreements are in effect, including ASEAN, yet the share that the agreement-partner countries occupy in China's total trade is not necessarily high.

Below, as case examples, we analyze the four agreements with ASEAN, Chile, Pakistan, and New Zealand which have their own respective distinctive features.

\section{TABLE 1.}

The Situation for China's Conclusion of FTAs (as of May 2012)

\begin{tabular}{|c|c|c|c|}
\hline $\begin{array}{l}\text { Current } \\
\text { Status }\end{array}$ & $\begin{array}{c}\text { Partner Country or } \\
\text { Region }\end{array}$ & Course of Negotiations & Current Status \\
\hline \multirow{4}{*}{$\begin{array}{l}\text { Effective } \\
\text { and Signed }\end{array}$} & ASEAN $^{1}$ & $\begin{array}{l}\text { Framework agreement } \\
\text { signed November 2002; } \\
\text { Goods agreement signed } \\
\text { November 2004; } \\
\text { Senvices agreement signed } \\
\text { January } 2007\end{array}$ & $\begin{array}{l}\text { Early Harvest measure } \\
\text { commenced January 2004; } \\
\text { Came into effect (goods) July } \\
2005 ; \\
\text { Came into effect (senvices) } \\
\text { July } 2007\end{array}$ \\
\hline & Hong Kong & Signed June 2003 & Came nto effect January 2004 \\
\hline & Macau & Signed October 2003 & $\begin{array}{l}\text { Came into effect January } \\
2004\end{array}$ \\
\hline & Chile & Commenced & Came into effect November \\
\hline
\end{tabular}




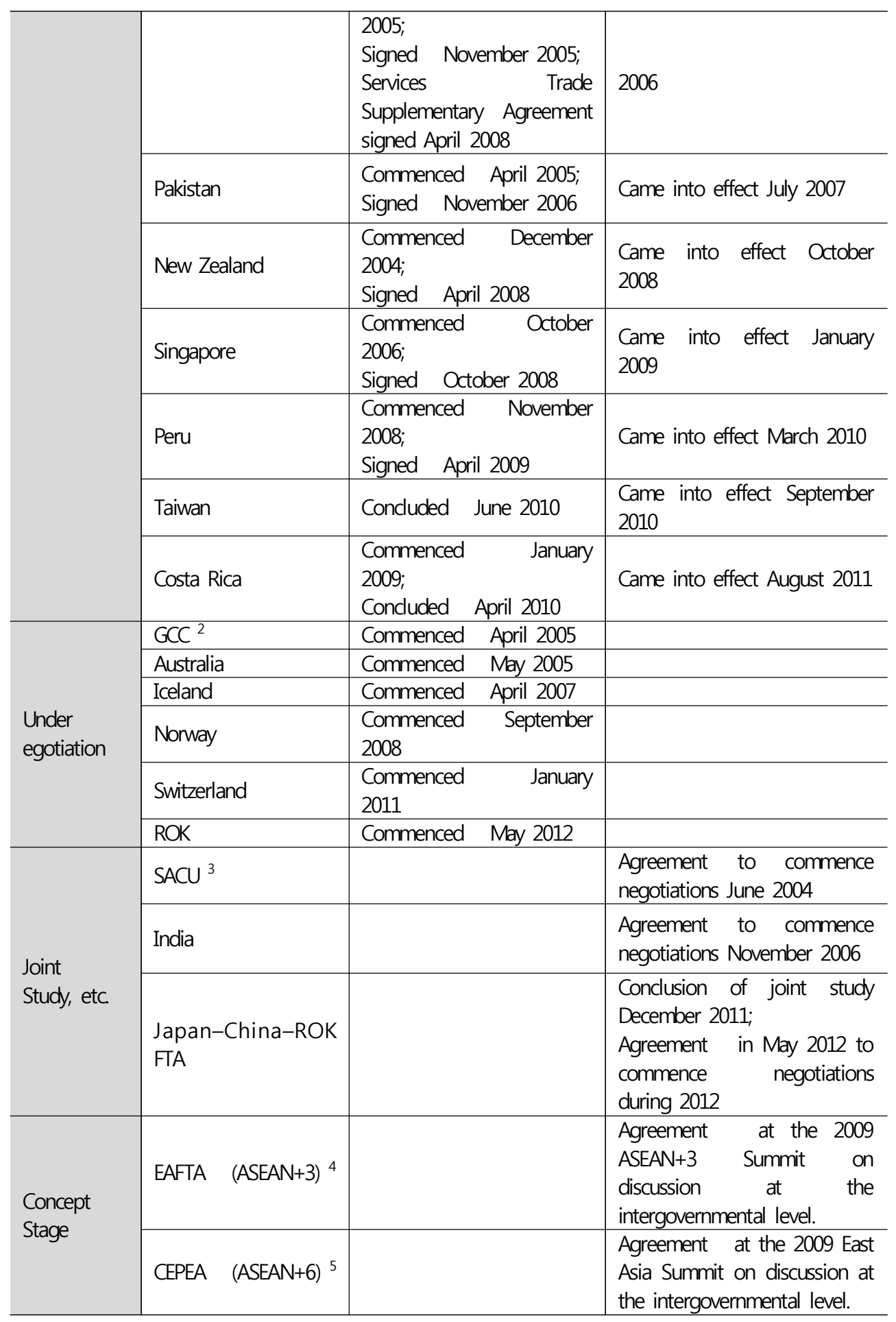


Notes: 1 The ten countries of: Brunei, Cambodia, Indonesia, Laos, Malaysia, Myanmar, the Philippines, Singapore, Thailand and Vietnam

2 A customs union of the six countries of: Saudi Arabia, the UAE, Oman, Qatar, Kuwait, and Bahrain

3 A customs union of the five countries of: South Africa, Botswana, Namibia, Swaziland, and Lesotho

4 ASEAN, Japan, China, and the ROK

5 ASEAN, Japan, China, the ROK, India, Australia, and New Zealand

Sources: Compiled by the author from a variety of materials, including JETRO (2011) and others

\section{(1) ASEAN}

Regarding the FTA with ASEAN, which was the first real FTA for China, the negotiations moved forward after its formal accession to the WTO. At the ASEAN+3 Summit held in Singapore in November 2000 China proposed joint study on an FTA with ASEAN. In the subsequent negotiations China set forth the following attractive conditions to ASEAN:

(i) Implementation of Early Harvest to implement the elimination of tariffs on agricultural products prior to the effectuation of an FTA;

(ii) Give a five-year deferment to the late-joining members of ASEAN (Vietnam, Laos, Myanmar, and Cambodia) on the implementation of the liberalization of trade;

(iii) China will give most-favored nation status to the ASEAN members which have not acceded to the WTO.

From among these Early Harvest in particular is considered a big plus for the ASEAN countries aiming to export to the Chinese market for tropical agricultural produce. Receiving such favorable conditions, the ASEAN side changed its attitude which initially had been passive on FTA negotiations, and agreed to the commencement of negotiations at the ASEAN+3 Summit held in Brunei in November 2001. Subsequently, at the ASEAN+3 Summit held in Phnom Penh, Cambodia, in November 2002, a "Framework Agreement on Comprehensive Economic Co-Operation" which formulated the content of Early Harvest was signed, and the lowering of tariffs for eight sectors of agricultural products began in January 2004. Subsequently, an agreement on trade in goods, which is the core of the FTA, was signed in November 
2004 and came into effect in July 2005, an agreement on trade in services was signed in January 2007 and came into effect in July of that year, and an agreement on investment was signed in August 2009 and came into effect in January 2010.

As reasons to advance the conclusion of an FTA with ASEAN, with China going as far as offering the favorable conditions mentioned above, there is much previous research which highlights the importance of political factors over economic ones. I list the important studies below:

(i) The securing of the lead in East Asian economic integration (in competitive relations with Japan) (Tran and Matsumoto (2007), Yang (2009))

(ii) The antagonism to the potential unipolar domination of the United States in East Asia (Hoadley and Yang (2010), Yang (2009))

(iii) The easing of the China Threat doctrine in both the economic and political spheres on the ASEAN side (Zhu (2003), Tran and Matsumoto (2007))

(iv) The development of the southwestern region of China, including Yunnan Province (Zhu (2003), Tran and Matsumoto (2007))

(v) Shouldering responsibility as an East Asian regional economic superpower (Zhu (2003))

Concerning economic factors meanwhile, Yang (2009) presents the opinion that the trade structure between China and ASEAN is not complementary, but rather, as it is competitive, the pluses for the Chinese economy of the FTA are not great. On the other hand, Tran and Matsumoto (2007) present the opinion that the economic effects of the FTA are promising, with the horizontal framework of the division of labor in manufacturing industry being formed, particularly regarding Thailand, Malaysia, Singapore and the Philippines within the founding members of ASEAN.

\section{(2) Chile}

Chile became the first FTA partner country outside Asia. Negotiations commenced in January 2005, an agreement was signed that November, and it came into effect in November 2006.

Chile is proactive on FTAs, and has already concluded FTAs with more than 30 countries. It can be said to have the presence of an FTA hub within South America. China, in the past, has suffered the disadvantage of competition with Mexican manufactured goods in the US market via the establishment of NAFTA. After this experience it has been cautious about an FTAA (Free Trade Area of the Americas) to encompass both American continents which was conceived at the time of the 
commencing of negotiations, and they made to further FTA negotiations with Chile as a bridgehead in South America to counter this (Hoadley and Yang (2010), Yang (2009)). In addition Chile was the first Latin American country to approve China's WTO accession, and was also the first Latin American country to acknowledge China as a "market economy". Such a diplomatic backdrop, in similar fashion to the example of New Zealand mentioned later, is seen as a factor promoting FTA negotiations (Hoadley and Yang (2010), Yang (2009)).

\section{(3) Pakistan}

Pakistan became the first FTA partner country in South Asia. The negotiations commenced in April 2005, an agreement was signed in November 2006, and it came into effect in July 2007. For China, Pakistan is in the position of a long-time ally in terms of security (Yang (2009)). The two countries both have an adversarial relationship with the South Asian giant of India. In addition Pakistan has always defended China's position, including on human rights issues and Taiwan. Moreover, China's economy has developed, and with its dependency on overseas energy rising, the strategic position of Pakistan, which neighbors the oil-producing nations of the Middle East, is increasing in importance.

In the meantime, the trade volume between the two countries is small, and it is hard to call economic relations close. It is possible to rate the FTA with Pakistan as a typical example where political factors in the security sphere have been greatly at work.

Moreover, as for the FTA with India, which has an adversarial relationship with Pakistan, they have finished the intergovernmental joint study, and while they announced an agreement to commence negotiations in November 2006, subsequently the negotiations have remained shelved.

\section{(4) New Zealand}

The FTA with New Zealand was the first with an OECD member country, and also at the current time is a unique one. The negotiations commenced in December 2004, an agreement was signed in April 2008, and it came into effect in October 2008. The FTA was the first comprehensive agreement for China, and from the beginning, in addition to trade in goods, included the areas of trade in services and investment. Furthermore, it has advanced content, incorporating agreements also on areas such as intellectual property rights and the movement of people.

As the reasons for China concluding an FTA with New Zealand, its first with a 
developed country, while several economic factors can be pointed out including that the economic scale is small and the negative effect on the Chinese economy is small, and that the trade structure is complementary, at the same time in political terms the diplomatic backdrop of being the first developed country to approve China's WTO accession and also the first developed country to acknowledge China as a "market economy" has had an effect (Hoadley and Yang (2010), Yang (2009)). This fact can be taken as collateral evidence that the FTA with Australia for which negotiations commenced at virtually the same time, in spite of it being regarded as being greater in terms of economic importance, has not yet been agreed.4)

Sorting the above four examples by the factor behind the conclusion of the FTAs, it appears they can be organized in a way where those with Chile and New Zealand have a mainly economic factor, that with Pakistan has a mainly political factor, and that with ASEAN has both political and economic aspects. In this way it is necessary to continue watching both the respective political and economic factors for the FTAs which China concludes. Furthermore, in the examples of Chile and New Zealand, which are considered to have the economic factor as the primary factor, it can be said that there was an economic diplomacy up to that point, with the backdrop of both countries receiving preferential treatment as negotiation partners. Therefore, even in the cases where economic factors are great, it can be said that focusing on the respective diplomatic relations is important.

\subsection{The Prospects for Subsequent FTA Policy}

Regarding the direction for China's subsequent conclusion of FTAs, as shown in Table 1, among the cases under negotiation at the present point in time Australia can be raised as the partner country which stands out. Moreover, the FTAs with large-scale advanced economies, such as the United States and the EU, are at the stage where not even a concept has been worked out. In addition, in the FTAs with developed countries, in the current situation, including intellectual property rights, environmental regulations, and labor issues, that difficult sectors for China's agreement are included in negotiations is the rule, and the hurdle of the commencement of negotiations is considered to be high.

Amid this, several moves can be seen regarding the ROK and Japan in Northeast Asia. First, regarding the bilateral FTA with the ROK, joint study has ended, intergovernmental prior consultation commenced in September 2010, and intergovernmental negotiations commenced in May 2012. Additionally, concerning the

4) Furthermore, after the commencement of the FTA with New Zealand, positive effects for China have occurred, including that Singapore, Malaysia, and Australia, aiming at commencement of negotiations with China, acknowledge it as a "market economy" (Hoadley and Yang (2010)). 
trilateral Japan-China-ROK FTA, the joint study at the governmental level ended in December 2011, and there has been agreement that intergovernmental negotiations will commence during 2012. Furthermore, the two East Asian wide-region FTA concepts of an EAFTA and a CEPEA are in existence, which include Japan, China, and the ROK as constituent members. Essentially, the trade structure between China on the one hand and Japan and the ROK on the other is complementary, and the economic effects of the FTA are promising. The conditions for China's FTA policy to be oriented in the direction of East Asia and Northeast Asia are being put in place.

\section{THE ROK'S FTA POLICY}

\subsection{The FTA Policy of the Roh Moo-hyun Administration}

Table 2 summarizes the situation for the ROK's conclusion of FTAs. The first FTA for the ROK was the ROK-Chile FTA, with negotiations commencing in 1999 under the Kim Dae-jung administration, and signed in 2003.

Next, the Roh Moo-hyun administration, which commenced in 2003, in spite of originally having a foundation of left-wing political forces, placed the focus on FTAs and promoted liberalization regarding its trade policy. For concrete policy management, they created the "FTA Roadmap" which indicated an FTA strategy prioritizing negotiations, etc., which is in Table 3, and accelerated FTA negotiations. Within it the neighboring nations of East Asia were designated as negotiating partners which should be prioritized in the short term, and based on this negotiations with Japan, Singapore and ASEAN were started.

Then learning from the delay in ratification of the $\mathrm{ROK}^{-}$Chile FTA, via the opposition of agricultural groups, etc., in June 2004 the "Procedures for the Conclusion of Free Trade Agreements" was stipulated in the form of a presidential directive. Based on this, an FTA Promotion Committee for deliberating on the fundamental direction of FTA policy, and beneath it an FTA Practice Consultation Committee, comprised of people at the vice-minister level from related ministries and agencies, and a Private FTA Council of Advisors of private-sector experts were established. Additionally, in October 2004, the FTA Negotiations Bureau (FTA Bureau) was established within the Office of the Minister for Trade of the Ministry of Foreign Affairs and Trade, taking aim at the practical work of FTA negotiations. Via these systemic adjustments, the FTA negotiation capacity of the ROK government was greatly strengthened.

Within the FTA negotiations with the countries of East Asia, negotiations with 
Singapore and ASEAN have proceeded smoothly, and have gone as far as the conclusion of FTAs, yet the negotiations with Japan were suspended in November 2004. The ROK government has officially explained the reason for that suspension as the passive attitude on the Japanese side relating to the elimination of tariffs on agricultural products. The viewpoint has also been offered, however, that the problem of agricultural products is not a genuine obstacle to this, and that the reason is that the ROK side was not able to uncover the advantages which would compensate for the disadvantages via the elimination of the tariffs on manufactured goods which were obviously expected.5)

Via the suspension of the Japan-ROK FTA negotiations the development of policy based on the "FTA Roadmap" suffered a setback. In its place the Roh Moo-hyun administration in February 2006 commenced FTA negotiations with the United States, a large-scale advanced economy, designated in the "FTA Roadmap" as a "long-term negotiations partner." For the negotiations which included many areas of conflicting interests, such as agricultural products, automobiles, and trade in services, initially it was viewed difficult to get an agreement, yet it was signed in June 2007 in the form of a sell-out.

KORUS FTA, seen from criteria such as the economic scale and amount of trade of the other country, can be called an unprecedented, large FTA for the ROK. Additionally, the content of that agreement is also of a high level, and trade in commodities has been practically $100 \%$ liberalized, including agricultural products, with the exception of rice, etc. ${ }^{6}$ ) In the services sector also the degree of liberalization is high, in addition the level of agreement even in areas including intellectual property rights and government procurement is high, and for East Asian FTAs it is of a type that has never been seen before.

Following this, the Roh Moo-hyun administration commenced negotiations in May 2007 with the EU, which is similarly designated a large-scale advanced economy. At this point in time it can be said that the "FTA Roadmap" has been shelved completely, and FTA strategy has been adopted which selects the partner by placing emphasis on the scale of the economy and the amount of trade.

5) For example Yamamoto (2008) summarizes the background to the negotiations and takes the main cause for their failure as "the ROK side not having the confidence that a Japan-ROK FTA would be win-win." Also, Cheong \& Cho (2007) for more detail regarding the ROK side's thinking in Japan-ROK negotiations.

6) According to Kuno \& Kimura (2008), in the case calculated on a tariff-line basis (on the basis of the number of goods), the US tariff elimination is $100 \%$, and that for the ROK is $99.7 \%$. This is greatly above the level of other examples of FTA liberalization in East Asia, including Japan. 
Volume 10, Number 3, December 2012, pp55 83

\section{TABLE 2.}

The Situation for the ROK's Conclusion of FTAs (as of May 2012)

\begin{tabular}{|c|c|c|c|}
\hline $\begin{array}{l}\text { Current } \\
\text { Status }\end{array}$ & $\begin{array}{l}\text { Partner Country } \\
\text { or Region }\end{array}$ & Course of Negotiations & Current Status \\
\hline \multirow[t]{8}{*}{$\begin{array}{l}\text { Effective } \\
\text { and Signed }\end{array}$} & Chile & $\begin{array}{l}\text { Commenced December } \\
\text { 1999; } \\
\text { Signed February } 2003\end{array}$ & $\begin{array}{l}\text { Came into effect } \\
\text { April } 2004\end{array}$ \\
\hline & Singapore & $\begin{array}{l}\text { Commenced January } \\
\text { 2004; } \\
\text { Signed Auqust } 2005\end{array}$ & $\begin{array}{l}\text { Came into effect } \\
\text { March } 2006\end{array}$ \\
\hline & EFTA $^{1}$ & $\begin{array}{l}\text { Commenced December } \\
\text { 2004; } \\
\text { Signed July } 2005\end{array}$ & $\begin{array}{l}\text { Came into effect } \\
\text { July } 2006\end{array}$ \\
\hline & ASEAN $\quad 2$ & $\begin{array}{l}\text { Commenced February } \\
\text { 2005; } \\
\text { Signed (goods) August } \\
\text { 2006; } \\
\text { Signed (services) } \\
\text { November } 2007\end{array}$ & $\begin{array}{l}\text { Came into effect } \\
\text { (goods) June 2007; } \\
\text { Came into effect } \\
\text { (services) May } 2009\end{array}$ \\
\hline & India & $\begin{array}{l}\text { Commenced February } \\
\text { 2006; } \\
\text { Signed August } 2009\end{array}$ & $\begin{array}{l}\text { Came into effect } \\
\text { January } 2010\end{array}$ \\
\hline & $\mathrm{EU}^{3}$ & $\begin{array}{l}\text { Commenced May 2007; } \\
\text { Signed October } 2010\end{array}$ & $\begin{array}{l}\text { Came into effect } \\
\text { July } 2011\end{array}$ \\
\hline & Peru & $\begin{array}{l}\text { Commenced March } \\
\text { 2009; } \\
\text { Signed March } 2011\end{array}$ & $\begin{array}{l}\text { Came into effect } \\
\text { August } 2011\end{array}$ \\
\hline & United States & $\begin{array}{l}\text { Commenced February } \\
\text { 2006; } \\
\text { Signed June } 2007\end{array}$ & $\begin{array}{l}\text { Coming into effect } \\
\text { likely }\end{array}$ \\
\hline \multirow[t]{9}{*}{$\begin{array}{l}\text { Under } \\
\text { Negotiation }\end{array}$} & Japan & $\begin{array}{l}\text { Commenced December } \\
2003\end{array}$ & $\begin{array}{l}\text { Negotiations } \\
\text { suspended since } \\
\text { November } 2004 \\
\end{array}$ \\
\hline & Canada & Commenced July 2005 & \\
\hline & Mexico & $\begin{array}{l}\text { Commenced August } \\
2007\end{array}$ & \\
\hline & $\mathrm{GCC}^{4}$ & Commenced & \\
\hline & Australia & Commenced & \\
\hline & New Zealand & Commenced June 2009 & \\
\hline & Colombia & $\begin{array}{l}\text { Commenced December } \\
2009\end{array}$ & \\
\hline & Turkey & Commenced April 2010 & \\
\hline & China & Commenced & \\
\hline
\end{tabular}




\begin{tabular}{|c|c|c|}
\hline \multirow[t]{7}{*}{$\begin{array}{l}\text { Joint } \\
\text { Study, etc. }\end{array}$} & Mercosur 5 & $\begin{array}{l}\text { Announcement of } \\
\text { research outcomes } \\
\text { October 2007; } \\
\text { Establishment of } \\
\text { Joint Consultative } \\
\text { Group July } 2009\end{array}$ \\
\hline & Vietnam & Joint $\quad$ study ongoing \\
\hline & Russia & Joint $\quad$ study ongoing \\
\hline & ${ }_{6}$ Central America & Joint study ongoing \\
\hline & Israel & Joint study ongoing \\
\hline & $\begin{array}{l}\text { Japan-China-ROK } \\
\text { FTA }\end{array}$ & $\begin{array}{l}\text { Joint study ended } \\
\text { December 2011; } \\
\text { Agreement in May } \\
2012 \text { on commencing } \\
\text { negotiations during } \\
2012\end{array}$ \\
\hline & SACU $^{7}$ & $\begin{array}{l}\text { Agreement on } \\
\text { commencement of } \\
\text { joint study }\end{array}$ \\
\hline \multirow[t]{2}{*}{$\begin{array}{l}\text { Concept } \\
\text { Stage }\end{array}$} & $\begin{array}{l}\text { EAFTA } \\
(A S E A N+3)^{8}\end{array}$ & $\begin{array}{l}\text { Agreement at the } \\
2009 \text { ASEAN+3 } \\
\text { Summit on discussion } \\
\text { at the } \\
\text { intergovernmental } \\
\text { level. }\end{array}$ \\
\hline & $\begin{array}{l}\text { CEPEA } \\
(\text { ASEAN+6) }\end{array}$ & $\begin{array}{l}\text { Agreement at the } \\
2009 \text { East Asia Summit } \\
\text { on discussion at the } \\
\text { intergovernmental } \\
\text { level. }\end{array}$ \\
\hline
\end{tabular}

Notes: 1 The Free Trade Association of the four countries of: Switzerland, Norway, Iceland, and Liechtenstein

2 The ten countries of: Brunei, Cambodia, Indonesia, Laos, Malaysia, Myanmar, the Philippines, Singapore, Thailand and Vietnam

3 A customs union of the twenty-seven countries of: Belgium, Germany, France, Italy, Luxembourg, the Netherlands, Denmark, Ireland, Britain, Greece, Spain, Portugal, Austria, Finland, Sweden, the Czech Republic, Estonia, Cyprus, Latvia, Lithuania, Hungary, Malta, Poland, Slovenia, Slovakia, Romania, and Bulgaria

4 A customs union of the six countries of: Saudi Arabia, the UAE, Oman, Qatar, Kuwait, and Bahrain

5 A customs union of the four countries of: Brazil, Argentina, Uruguay, and Paraguay 
6 The five countries of: Costa Rica, Panama, Guatemala, Honduras, and the Dominican Republic

7 A customs union of the five countries of: South Africa, Botswana, Namibia, Swaziland, and Lesotho

8 ASEAN, Japan, China, and the ROK

9 ASEAN, Japan, China, the ROK, India, Australia, and New Zealand

Sources: Compiled by the author from a variety of materials, including JETRO (2011) and others

TABLE 3.

The Ranking of Partner Countries within the "FTA Roadmap"

\begin{tabular}{l|l}
\hline \multicolumn{1}{c|}{ Time Period } & \multicolumn{1}{c}{ Partner Country or Region } \\
\hline Short-Term & Japan, Singapore, Mexico, Canada, India, and ASEAN \\
\hline $\begin{array}{l}\text { Medium-to-Lon } \\
\text { g Term }\end{array}$ & United States, China, EU, Mercosur, Russia, Japan-China-ROK FTA, \\
\hline Reference \\
only
\end{tabular}

3.2 The FTA Policy of the Lee Myung-bak Administration and the Future Prospects thereof

Regarding the Lee Myung-bak administration which commenced in February 2008, the Grand National Party (Hannara), taking the conservative classes as a political base, and which became the ruling party, basically had a pro-FTA stance from the time of the Roh Moo-hyun administration when it was the opposition party. Consequently, after the change in administration, the Lee administration took a form inheriting the FTA policy of the previous Roh administration, and came to inherit the two great leftover challenges of ratifying KORUS FTA and the conclusion of an ROK-EU FTA.

The Obama administration, which commenced in 2009, initially adopted a cautious attitude concerning the ratification of KORUS FTA, and although there was a state of affairs where progress could not be seen, it was decided that in October 2011 the US Congress and in November the same year the ROK National Assembly would ratify it and it would go into effect.

Meanwhile, regarding the ROK-EU FTA, it reached the signing stage in October 2010, in spite of having sectors with rigorous conflicts of interest, including automobiles, and came into effect in July 2011. Its content was almost on a par with that of KORUS FTA, and became something with a high-level of liberalization.

In FTAs other than these, FTAs came into effect with India in January 2010 and 
Peru in August 2011, respectively.

Table 4 shows the trade ratios with the nations with which the ROK has concluded FTAs. In terms of trade ratios with countries where an FTA was in effect as of July 2009, in the ROK case it has stalled at $12.1 \%$, and was behind Japan. When you add the United States, India and the EU, however, the trade ratio rises to $35.3 \%$, and reaches a level that surpasses the likes of the United States and China. Furthermore, at the stage when those three countries or regions have been added, the GDP of the nations with which the ROK has concluded an FTA reaches $60 \%$ of that for the entire world. Seen from these indices, it can be read that the recent progress in FTA policy is something of significance.

\section{TABLE 4.}

The Trade Ratios for the Major Nations which have Concluded FTAs with the ROK

\begin{tabular}{|c|c|c|c|c|c|c|c|c|c|c|c|}
\hline & \multicolumn{5}{|c|}{$\begin{array}{c}\text { ROK } \\
\text { (2008 trade amount basis) }\end{array}$} & \multicolumn{6}{|c|}{$\begin{array}{c}\text { Major Country } \\
\text { (2007 trade amount basis) }\end{array}$} \\
\hline & $\begin{array}{r}\text { Count } \\
\text { whi } \\
\text { ef } \\
\text { (as c } \\
20\end{array}$ & $\begin{array}{l}\text { S for } \\
\text { in } \\
\text { July } \\
\text { July }\end{array}$ & US & $\begin{array}{c}\text { Indi } \\
\text { a }\end{array}$ & EU & US & $\begin{array}{l}\text { Chi } \\
\text { na }\end{array}$ & $\begin{array}{c}\text { Jap } \\
\text { an }\end{array}$ & $\begin{array}{l}\text { Sin } \\
\text { ga } \\
\text { por } \\
\text { e }\end{array}$ & $\begin{array}{c}\text { Chil } \\
\mathrm{e}\end{array}$ & $\begin{array}{l}\mathrm{Ne} \\
\mathrm{w} \\
\text { Zea } \\
\text { lan } \\
d\end{array}$ \\
\hline \multirow{2}{*}{$\begin{array}{l}\text { F T A } \\
\text { Trade } \\
\text { Ratio } \\
\text { (\%) }\end{array}$} & Ratio & 12.1 & 9.9 & 1.8 & 11.5 & \multirow[t]{2}{*}{34.0} & \multirow[t]{2}{*}{19.7} & \multirow[t]{2}{*}{14.7} & \multirow[t]{2}{*}{67.7} & \multirow[t]{2}{*}{83.2} & \multirow[t]{2}{*}{37.0} \\
\hline & $\begin{array}{l}\text { Cum } \\
\text { Total }\end{array}$ & 12.1 & 22.0 & 23.8 & 35.3 & & & & & & \\
\hline
\end{tabular}

Source: Ministry of Strategy and Finance, ROK (2009)

Amid such circumstances, in March 2009 President Lee Myung-bak, on a visit to Jakarta, presented the "New Asia Initiative". Raised within it as one of the most important items was that: "The ROK assumes the role of the hub of an Asian FTA network, and aims for the early conclusion of FTAs with all of the countries within the region". Although concrete procedures were not indicated in the initiative, the ROK has again demonstrated its continuing emphasis on Asia in its FTA strategy, after the completion of FTAs with both of the large-scale economies of the United States and the EU.

As actual moves, regarding the Japan-ROK FTA, after the start of the Lee Myung-bak administration moves were seen to recommence the negotiations which had been suspended since 2004, yet in the current situation these have stalled at a working-level preparatory-negotiation stage. Meanwhile, as stated above regarding a bilateral FTA with China, and a China-Japan-ROK FTA, progress is seen for both 
respectively. The conditions are being put in place for the ROK's FTA strategy as with China, including an EAFTA and a CEPEA, to come back to East Asia and Northeast Asia.

\section{JAPAN'S FTA POLICY}

Looking back at Japan's FTA policy, at the initial stage when negotiations for concluding FTAs were commenced, its consistent strategic quality was poor in the selection of FTA partner countries. Table 5 brings together the information on Japan's FTAs. It is considered that Singapore, the first partner country, was chosen solely because of the ease of negotiation. Additionally in the case of Mexico, the second partner country, the reason was that Japanese firms would be placed at a disadvantage in the Mexican market as the NAFTA member had additionally concluded an FTA with the EU. Therefore negotiations were commenced with the tangible requirement for conclusion of FTAs coming from the economic realm. It can be said that both of them are negotiations commenced due to a particular rationale.

Regarding the ROK and countries of ASEAN which followed these, however, the geographical factor of being in East Asia can be raised as a common reason. "Japan's FTA Strategy", which brought together the thinking of the Economic Affairs Bureau of the Ministry of Foreign Affairs in October 2002, is seen as the first government document that undertook a comprehensive examination on the approaches on Japan's FTA strategy, but in the section within it dealing with the strategic order of priority for FTAs, it raises into first place an "Economic partnership in East Asia revolving around Japan, the Republic of Korea, and China, plus ASEAN". Amidst all this, the "ASEAN-Japan Comprehensive Economic Partnership Concept" was presented on Prime Minister Junichiro Koizumi's historic visit to Southeast Asian countries in the same year. This has been rated also as a first for Japan's ASEAN-FTA strategy.

Subsequently, in the "Basic Policy towards further promotion of Economic Partnership Agreements (EPAs)", approved by the Council of Ministers on the Promotion of Economic Partnership in 2004, a focus on East Asia for partner countries was specified, and the strategic approach on FTAs came to have more concreteness.

Moreover, in the "Global Economic Strategy", decided on in the Council on Economic and Fiscal Policy and formulated by the Ministry of Economy, Trade and Industry in 2006, the promoting of FTAs in the framework of ASEAN+6 (Japan, China and the ROK, and India, Australia, and New Zealand) was specified, and a concrete time schedule relating to that was also indicated. Furthermore, in the "Economic Growth Initiative" created based upon that, a target figure was raised of 
over $25 \%$ of the total trade volume being with countries with which an FTA had been concluded by 2010. Japan's FTA policy in it can be said to have had an explicit strategy. The ASEAN-Japan Comprehensive Economic Partnership (AJCEP) which came into effect in 2010 appears to be designated as the first fruit thereof.

The evolution of subsequent FTA policy, however, has stopped at a sluggish pace. As of August 2011, twelve agreements were in effect, but amongst them six were with ASEAN members, and are agreements overlapping with AJCEP, and only India could be raised as a new large partner country. In addition at that point in time, regarding agreements with China and the ROK, the Japan-ROK negotiations are in a state of suspension, the Japan-China-ROK FTA is under joint study, and an EAFTA and a CEPEA have also stopped at the concept stage.7)

\section{TABLE 5.}

The Situation for Japan's Conclusion of FTAs (as of May 2012)

\begin{tabular}{|c|c|c|c|}
\hline $\begin{array}{l}\text { Current } \\
\text { Status }\end{array}$ & $\begin{array}{c}\text { Partner Country or } \\
\text { Region }\end{array}$ & Course of Negotiations & Current Status \\
\hline \multirow[t]{11}{*}{$\begin{array}{l}\text { Effective } \\
\text { and Signed }\end{array}$} & Singapore & $\begin{array}{l}\text { Commenced January 2001; } \\
\text { Signed January } 2002\end{array}$ & $\begin{array}{l}\text { Came into effect } \\
\text { November } 2002\end{array}$ \\
\hline & Mexico & $\begin{array}{l}\text { Commenced November 2002; } \\
\text { Signed September 2004 }\end{array}$ & $\begin{array}{l}\text { Came into effect April } \\
2005\end{array}$ \\
\hline & Malaysia & $\begin{array}{l}\text { Commenced December 2004; } \\
\text { Signed July } 2005\end{array}$ & $\begin{array}{l}\text { Came into effect July } \\
2006\end{array}$ \\
\hline & Chile & $\begin{array}{l}\text { Commenced February 2006; } \\
\text { Signed August } 2009\end{array}$ & $\begin{array}{l}\text { Came into effect January } \\
2010\end{array}$ \\
\hline & Thailand & $\begin{array}{l}\text { Commenced February 2004; } \\
\text { Signed April } 2007\end{array}$ & $\begin{array}{l}\text { Came into effect } \\
\text { November } 2007\end{array}$ \\
\hline & Brunei & $\begin{array}{l}\text { Commenced June 2006; } \\
\text { Signed June } 2007\end{array}$ & $\begin{array}{l}\text { Came into effect July } \\
2008\end{array}$ \\
\hline & Indonesia & $\begin{array}{l}\text { Commenced April 2005; } \\
\text { Signed April } 2008\end{array}$ & $\begin{array}{l}\text { Came into effect July } \\
2008\end{array}$ \\
\hline & ASEAN 1 & $\begin{array}{l}\text { Commenced February 2006; } \\
\text { Signed August } 2009\end{array}$ & $\begin{array}{l}\text { Came into effect January } \\
2010\end{array}$ \\
\hline & Philippines & $\begin{array}{l}\text { Commenced February 2004; } \\
\text { Signed September } 2006\end{array}$ & $\begin{array}{l}\text { Came into effect } \\
\text { December } 2008\end{array}$ \\
\hline & Switzerland & $\begin{array}{l}\text { Commenced May 2007; } \\
\text { Signed September } 2008\end{array}$ & $\begin{array}{l}\text { Came into effect } \\
\text { September } 2009\end{array}$ \\
\hline & Vietnam & $\begin{array}{l}\text { Commenced January 2007; } \\
\text { Signed December } 2008\end{array}$ & $\begin{array}{l}\text { Came into effect October } \\
2009\end{array}$ \\
\hline
\end{tabular}

7) Meanwhile amidst all this, the commencing of preparatory negotiations with the EU in May 2011, after the Great East Japan Earthquake, can be raised as a noteworthy move. 


\begin{tabular}{|c|c|c|c|}
\hline & India & $\begin{array}{l}\text { Commenced January 2007; } \\
\text { Signed February } 2011\end{array}$ & $\begin{array}{l}\text { Came into effect August } \\
2011\end{array}$ \\
\hline & Peru & $\begin{array}{l}\text { Commenced May 2009; } \\
\text { Signed May } 2011\end{array}$ & \\
\hline \multirow[t]{3}{*}{$\begin{array}{l}\text { Under } \\
\text { Negotiation }\end{array}$} & ROK & Commenced December 2003 & $\begin{array}{l}\text { Negotiations suspended } \\
\text { since November } 2004\end{array}$ \\
\hline & $\mathrm{GCC}^{2}$ & Commenced April 2006 & \\
\hline & Australia & Commenced April 2007 & \\
\hline \multirow[t]{3}{*}{$\begin{array}{l}\text { Joint Study, } \\
\text { etc. }\end{array}$} & $\mathrm{EU}^{3}$ & & $\begin{array}{l}\text { Commencement of } \\
\text { preparatory negotiations } \\
\text { May } 2011\end{array}$ \\
\hline & $\begin{array}{l}\text { Japan-China-ROK } \\
\text { FTA }\end{array}$ & & $\begin{array}{l}\text { Condusion of joint study } \\
\text { December 2011; } \\
\text { Agreement in May } 2012 \\
\text { to commence negotiations } \\
\text { during } 2012\end{array}$ \\
\hline & TPP ${ }^{4}$ & & $\begin{array}{l}\text { Announcement of } \\
\text { participation in negotiations }\end{array}$ \\
\hline \multirow[t]{2}{*}{$\begin{array}{l}\text { Concept } \\
\text { Stage }\end{array}$} & $\begin{array}{l}\text { EAFTA } \\
(\text { ASEAN+3) } 5\end{array}$ & & $\begin{array}{l}\text { Agreement at the } 2009 \\
\text { ASEAN+3 Summit on } \\
\text { discussion at the } \\
\text { intergovernmental level. }\end{array}$ \\
\hline & CEPEA $\quad\left(\right.$ ASEAN+6) ${ }^{6}$ & & $\begin{array}{l}\text { Agreement at the } 2009 \\
\text { East Asia Summit on } \\
\text { discussion at the } \\
\text { intergovernmental level. }\end{array}$ \\
\hline
\end{tabular}

Notes: 1 The ten countries of: Brunei, Cambodia, Indonesia, Laos, Malaysia, Myanmar, the Philippines, Singapore, Thailand and Vietnam

2 A customs union of the six countries of: Saudi Arabia, the UAE, Oman, Qatar, Kuwait, and Bahrain

3 A customs union of the twenty-seven countries of: Belgium, Germany, France, Italy, Luxembourg, the Netherlands, Denmark, Ireland, Britain, Greece, Spain, Portugal, Austria, Finland, Sweden, the Czech Republic, Estonia, Cyprus, Latvia, Lithuania, Hungary, Malta, Poland, Slovenia, Slovakia, Romania, and Bulgaria

4 An FTA under negotiation by the nine countries of: New Zealand, Chile, Singapore, Brunei, the United States, Australia, Peru, Vietnam, and Malaysia

5 ASEAN, Japan, China, and the ROK

6 ASEAN, Japan, China, the ROK, India, Australia, and New Zealand

Sources: Compiled by the author from a variety of materials, including JETRO (2011) and others 


\section{THE TPP AND EAST ASIAN ECONOMIC INTEGRATION}

\subsection{The FTAAP Concept and the Substantiation of the TPP}

The FTA policies of China, the ROK and Japan, tracing the path as mentioned above, the systemic integration of Northeast Asia, and what is more of the whole of East Asia, has been continuing in a state where it has not always been developing smoothly. Amidst this, the United States, which is the one major trading nation in the Asia-Pacific, came up with an East Asian trade policy to counter EAFTA, CEPEA and the like, taking APEC (Asia-Pacific Economic Cooperation) as its stage. That is namely the FTAAP concept (Free Trade Area of the Asia-Pacific) covering APEC in its entirety. This background is as summarized in Table 6. Japan also responded to this move, and in "The New Growth Strategy (Basic Policies)" which the Hatoyama administration announced in November 2009, the drawing-up of a roadmap to build an FTAAP with 2020 as the target year was specified.

On the other hand, however, an FTAAP, having an area encompassing major global trading nations such as Japan, the United States, and China, will involve the need to accommodate a large number of interests, and it is considered that in the short term the reaching of agreement will be difficult. With that, as a step to an FTAAP, they adopted a strategy to carry out in advance a voluntary FTA from among APEC members, namely the TPP (Trans-Pacific Partnership). $\left.{ }^{8}\right)$

The Bush administration in September 2008 announced participation in the Trans-Pacific Strategic Economic Partnership (P4, later the TPP), an FTA by the four countries of Singapore, New Zealand, Chile and Brunei. With the changeover to the Obama administration, the participation of the United States in talks on the TPP was later than initially planned, but in March 2010 the United States also took part, and official talks were commenced. In addition Australia, Peru, Vietnam, and Malaysia also joined in, and currently negotiations by the nine nations are ongoing.

Meanwhile, the Kan administration of Japan announced examination of participation in TPP negotiations in October 2010. At the 18th APEC summit held in Yokohama in November of that year, the TPP, along with EAFTA and CEPEA, was designated as one of the concrete paths toward the realization of an FTAAP. The fact that the three were included in the agreement enables a certain amount of consideration and interpretation for the positions of the countries of East Asia in APEC, and particularly for China. Urata (2011), however, pointed out the superiority of the TPP at that same point in time, from the fact that the other two have stalled at

8) For more detail on this background see Nakajima (2010b). 
the concept stage.

In terms of content the TPP has basically not sanctioned any items for exemption from the elimination of tariffs, and is heading in the direction of an advanced "twenty-first century" FTA, aiming at comprehensive agreement even on sectors that are outside trade in goods, including services, investment and intellectual property rights.9) If such a consensus building of high-level liberalization can be done via the TPP negotiations, it will form in advance the liberalization rules for a future FTAAP.

On the other hand, if the scope of the TPP were to stop at the nations currently participating in negotiations, it would inevitably be limited in terms of its actual economic effects. Many of the nations currently participating in negotiations have been relatively active on FTAs to date, and according to Scollay (2011), of the 36 pairings (dyads) among the 9 nations, 25 were already covered by an existing FTA. Moreover, many of the nations currently participating in negotiations are small in economic scale, and the fact that the trade volumes between the various nations are small, except for trade with the United States, has also been a factor that has limited the economic effects. ${ }^{10)}$

In order also to expand such direct economic effects for the TPP, it has been necessary to expand its scope. In addition, the expansion of participating nations has been indispensible because of its aforementioned role as a path toward an FTAAP. It could be said that in the Asia-Pacific region, the three Northeast Asian nations of Japan, China and the ROK, from the scales of their economies and trade, are a particularly important presence as future participants in the TPP.

\subsection{The Effects of Japan's Participation in the TPP Negotiations}

In such a situation, Prime Minister Noda announcement11) of participation in the TPP negotiations at the 19th APEC summit held in Honolulu in November 2011 was to have major repercussions for the Asia-Pacific region FTA negotiations. As an immediate effect, both Canada and Mexico announced their participation in the TPP negotiations at the same summit.

9) At the TPP negotiations 24 working groups have been set up, and in addition to market access, place-of-origin regulations, trade facilitation, service trade, investment, the environment, and labor, etc., sectors are included for which hitherto there have not been cases of handling within an FTA, such as small and medium-sized enterprises and regulatory cooperation (for more detail please see Barfield (2011) and Kimura (2011)).

10) Scollay (2011) points out the mutual incompatibility of the expansion of participating nations with the high-quality targets for a TPP FTA.

11) To be exact he made the following announcement: "to enter into consultations toward participating in the TPP negotiations with the countries concerned" (11 November 2011 press conference). 
Furthermore Japan's announcement of participation had a great impact also on the foreign policy of East Asian nations, including both the Northeast Asian countries of China and the ROK, and the nations of ASEAN, etc., not participating in the TPP negotiations.

Regarding China, on which the most interest is focused, President $\mathrm{Hu}$ Jintao, immediately after the announcement made a statement indicating understanding for Japan's participation in the TPP negotiations; officially they have indicated a cool, detached reaction. On the other hand, however, as an example, Li Xiangyang, Director of the Institute of Asia-Pacific Studies, Chinese Academy of Social Sciences, a government-affiliated think tank regarded as having a certain influence in the formation of foreign policy, criticized the TPP in the Japanese media as a policy instrument aimed at a return to Asia not just for the US economy, but also within the sphere of security, and has stated that Japan's participation in it is also an attempt to shift foreign policy to an emphasis on the United States over China. ${ }^{12)}$ In the current situation, we can infer that the Chinese government also has a sense of caution that the TPP-in which China's immediate participation can be called difficult in such areas as intellectual property rights, environmental regulations, state-owned enterprises, and labor problems ${ }^{-}$will become the standard model for the economic integration of the Asia-Pacific region.

For the ROK meanwhile, as it has either already concluded bilateral agreements or is in negotiations with many of the TPP-participating nations, there is no immediate concern of there being any economic detriment. Consequently, it is considered to take the position of assessing the TPP subsequently, including the success or failure of Japan's participation in negotiations.

Within ASEAN, Indonesia, which is the major country not participating in the TPP negotiations, has shown the strongest opposition. The ASEAN members of Singapore, Malaysia, Vietnam, and Brunei have been taken into the TPP, the concept of economic integration with ASEAN at its core has crumbled, and what's more it appears that there is concern that the centripetal force of ASEAN itself will diminish.

\subsection{The Outlook for the Future}

What kind of impact will Japan's participation in the TPP negotiations have on the course of subsequent East Asian economic integration?

What are considered will be greatly influenced first are the two broad economic integration concepts having ASEAN at their core: ASEAN+3 (EAFTA) and ASEAN+6 (CEPEA). Regarding this, new moves were already seen at the stage when Japan

12) Nihon Keizai Shimbun, 1 January 2012, morning edition. 
began examination of participation in the TPP negotiations. To begin with, as a main cause that the realization of both concepts is delayed has been a bilateral conflict between China, which advocates ASEAN+3, and Japan, which insists on the promotion of ASEAN+6 which adds in India, Australia and New Zealand, and is concerned about the expansion of China's influence. However, at the ASEAN+6 Economic Ministers Meeting held in August 2011, a proposal was made jointly regarding the setting-up of working groups for the three areas of "trade in goods", "trade in services", and "investment", which are the focus of FTA negotiations, in order to move forward the EAFTA and CEPEA which are frozen for the two countries of Japan and China. Such moves are evidently things that have been touched off by the TPP negotiations, and it can be said that clear changes have occurred in China's FTA strategy. Following that, after the Honolulu APEC summit, at the ASEAN+3 Summit Meeting and East Asia Summit held in November on Bali, Indonesia, the setting-up of working groups for the three areas was agreed, and it can be said that there was definite progress for both concepts.

As one more major move aiming at East Asian economic integration there is the Japan-China-ROK trilateral FTA touched on earlier. Regarding that, the research group from industry, government and academia that has been held since 2010 submitted a final report in December 2011, and agreement was made on the commencing of official talks during 2012. It appears that for these also Japan's participation in the TPP negotiations has given a push to the decision-making of both China and the ROK.

Comparing the above two categories, the Japan-China-ROK FTA, that procedurally defined the entering into official talks, has taken on a form with a head start on the EAFTA and CEPEA. In addition, viewed also from the number of countries participating in negotiations, it is expected that progress on the Japan-ChinaROK FTA will come earlier. Meanwhile, if the Northeast Asian Japan-China-ROK FTA comes to be concluded first, it can also be considered that the East Asian economic integration to date that has been promoted with ASEAN as its core will approach a major turning point.

As to which one to go for in the broader economic integration of the Asia-Pacific region concerning Japan, it is predicted that procedurally they will be moved forward in the order of: the TPP; the Japan-China-ROK FTA; the EAFTA; and the CEPEA.

\section{CONCLUSION}

Considering the content of the FTAs, then for the Japan-China-ROK FTA, the 
EAFTA and the CEPEA, which include China as a member, reaching high-level agreement on areas such as intellectual property rights will be difficult. On the other hand, however, considering that China maintains the obstacles, including the remaining high tariffs in the trade in goods, including manufactured goods, then even if there is an FTA with a main content of the liberalization of trade in goods, it could be said to be something that contains great advantages for Japan (or the ROK). Therefore, for the foreseeable future, for Japan it is considered that there is a rational choice: by aiming at advanced content such as intellectual property rights, environmental regulations, state-owned enterprises, and labor problems within the TPP; or conversely aiming at a conventional-style tariff elimination in the Japan-China-ROK FTA, or the EAFTA and the CEPEA.

Furthermore, in the medium-to-long-term, after passing through such an intermediate stage, the continued developing and deepening of the TPP and other wide-region FTAs toward an FTAAP covering East Asia in its entirety, including China, will be the most favorable scenario for the Asia-Pacific region.

TABLE 6.

Moves concerning FTAAP and TPP

\begin{tabular}{|c|c|c|}
\hline Year & Month & Particulars \\
\hline 2004 & November & $\begin{array}{l}\text { At the 12th APEC summit held in Santiago, Chile, ABAC proposed } \\
\text { an FTAAP }\end{array}$ \\
\hline \multirow[t]{2}{*}{2006} & July & $\begin{array}{l}\text { The coming into effect of the Trans-Pacific Strategic Economic } \\
\text { Partnership Agreement (P4) (Member states: Singapore, New } \\
\text { Zealand, Chile and Brunei) }\end{array}$ \\
\hline & November & $\begin{array}{l}\text { At the 14th APEC summit held in Hanoi, Vietnam an FTAAP was } \\
\text { raised as a topic for discussion }\end{array}$ \\
\hline \multirow[t]{2}{*}{2008} & September & $\begin{array}{l}\text { The Office of the United States Trade Representative officially } \\
\text { announced participation in the P4 }\end{array}$ \\
\hline & November & Australia and Peru indicated their participation in the P4 (see note) \\
\hline \multirow[t]{3}{*}{2009} & November & $\begin{array}{l}\text { US President Obama officially announced participation in the TPP } \\
\text { in a speech in Tokyo }\end{array}$ \\
\hline & November & $\begin{array}{l}\text { At the 17th APEC summit held in Singapore, the continuation of } \\
\text { examination of the concept of an FTAP was incorporated in the } \\
\text { declaration }\end{array}$ \\
\hline & December & $\begin{array}{l}\text { In "The New Growth Strategy (Basic Policies)" which the Hatoyama } \\
\text { administration announced, it was specified that Japan would } \\
\text { prepare a roadmap toward the establishment of an FTAP, with } \\
2020 \text { as the target year }\end{array}$ \\
\hline 2010 & March & $\begin{array}{l}\text { The first negotiations began for the TPP adding the United States, } \\
\text { Australia, Peru and Vietnam (initially participation as observers, }\end{array}$ \\
\hline
\end{tabular}




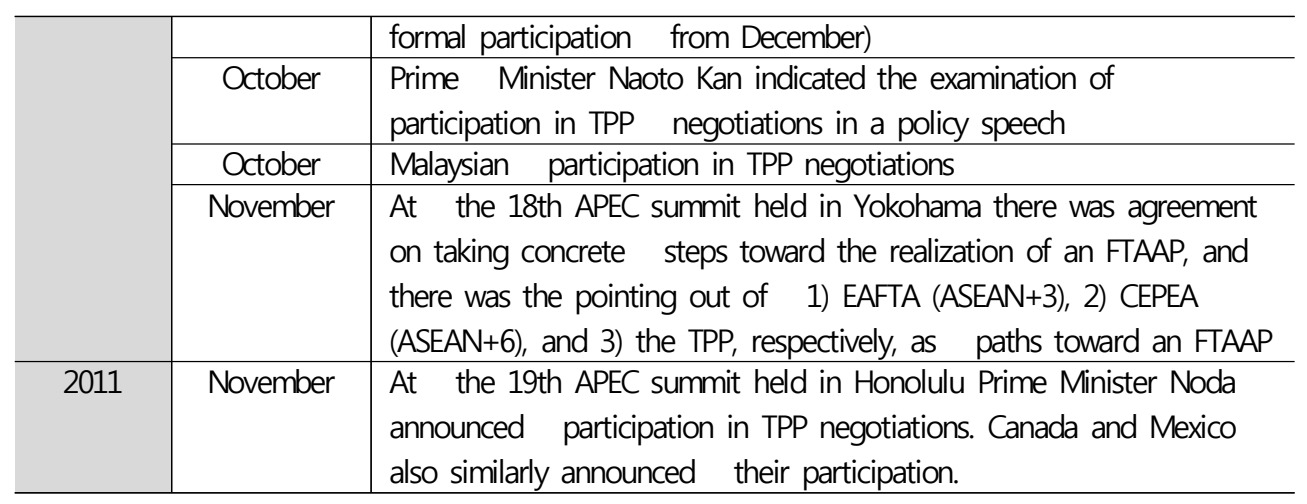

Source: Compiled by the author from various materials

Note: From that time on the expanded P4 came to be referred to as the Trans-Pacific Partnership (TPP) (Scollay (2010)). 


\section{REFERENCES}

\section{In Japanese}

Cheong, Inkyo, and Cho, Jungran (2007), "Kan-Nichi FTA wa kanō nanoka-Kankoku no FTA seisaku no kōsatsu oyobi Kan-Nichi FTA kōshō ni taisuru shisa" [The Progress of Korea's FTA Policy and Implications for an FTA between Japan and Korea], ERINA Report, Vol. 76, Economic Research Institute for Northeast Asia (ERINA), Niigata, Japan

Economic Affairs Bureau, Ministry of Foreign Affairs of Japan (2002), Nihon no FTA senryaku [Japan's FTA Strategy]

Japan External Trade Organization (JETRO) (2011), Sekai to Nihon no juyō-na FTA ichiran [A Synopsis of the Main Global and Japanese FTAs], Japan External Trade Organization (JETRO)

Kimura, Fukunari (2011), "Higashi Ajia no seichō to Nihon no gurōbaru senryaku" [East Asia's Growth and Japan's Global Strategy], Chapter 15 in Keiichi Umada, Shujiro Urata and Fukunari Kimura (eds.) Nihon tsūshō seisaku-ron [Japan's Trade Policy], Bunshindo

Kuno, Arata, and Kimura, Fukunari (2008), "Hokutō Ajia to FTA: Kadai to tenbō" [Northeast Asia and FTAs: Issues and Perspectives], ERINA Report, Vol. 82, Economic Research Institute for Northeast Asia (ERINA), Niigata, Japan

Nakajima, Tomoyoshi (2009), "Kankoku no FTA seisaku-Sono gaikatsu to keizai kōka bunseki" [The ROK's FTA Policy: Summary and Analysis of the Economic Effects], Chapter 8 in Suh Sung and Lee Kang-kook (eds.), Kan-Bei FTA to Kankoku keizai no kiki [The ROK-USA FTA and the ROK Economic Crisis], Koyo Shobo

Scollay, Robert (2010), "Kan-Taiheiyō pātonāshippu (TPP) kyōtei-Hajimari, igi oyobi mitooshi" [The Trans-Pacific Partnership: Origins, significance and outlook], Ajiken World Trend, No. 183, IDE, JETRO

Tran, Van Tho, and Matsumoto, Kunichika (2007), "ASEAN-Chūgoku no FTA no seijikeizaigaku" [The Politico-Economy of the ASEAN-China FTA], Chapter 2 in Tran Van Tho, and Kunichika Matsumoto (eds.) Chūgoku-ASEAN no FTA to Higashi Ajia keizai [The China-ASEAN FTA and the East Asian Economy], Bunshindo

Urata, Shujiro (2011), "APEC no arata-na tenkai to Nihon no taiō" [APEC's New Developments and Japan's Responses], Chapter 7 in Keiichi Umada, Shujiro Urata and Fukunari Kimura (eds.) Nihon tsūshō seisaku-ron [Japan's Trade Policy], Bunshindo 
Yamamoto, Eiji (2008), "Nichi-Kan FTA-EPA-Kyōjun to kōshō saikai ni muketa tenbō" [Japan-ROK FTA or EPA: The Lessons and Prospects for the Recommencement of Negotiations], New ESRI Working Paper Series, No. 6, Economic and Social Research Institute, Cabinet Office (Japan)

Zhu, Yan (2003), "Chūgoku no jiyū bōeki kyōtei-e no apurōchi to sono eikyō" [China's Approach to the Free Trade Agreement and Its Influence], Economic Review, Vol. 7, No. 2, Economic Research Center, Fujitsu Research Institute

\section{In English}

Barfield, Claude, and Levy, P.I. (2009), "Tales of the South Pacific: President Obama and the Transpacific Partnership", International Economic Outlook, No 2, American Enterprise Institute, Washington DC, December 2009

Barfield, Claude (2011), "The Trans-Pacific Partnership: A Model for Twenty-First-Century Trade Agreements?", International Economic Outlook, No. 2, American Enterprise Institute, Washington DC, June 2011

Hoadley, S., and J. Yang (2010), “China's Free Trade Negotiations: Economics, Security and Diplomacy" in Saori N. Katada and Mireya Solis (eds.) Cross Regional Trade Agreements: Understanding Permeated Regionalism in East Asia, Springer, Germany

Kwei, Elaine S. (2006), "Chinese Trade Bilateralism: Politics Still in Command", in Vinod K. Aggarwal and Shujiro Urata (eds.), Bilateral Trade Agreements in the Asia-Pacific, Routledge, UK

Nakajima, Tomoyoshi (2010a), "The ROK's FTA Policy: Developments under the Lee Myung-bak Administration", ERINA Discussion Paper, No. 1002e, Economic Research Institute for Northeast Asia (ERINA), Niigata, Japan

Nakajima, Tomoyoshi (2010b), "APEC: The Future Prospects for a Bridge Spanning the Pacific", ERINA Discussion Paper, No. 1003e, Economic Research Institute for Northeast Asia (ERINA), Niigata, Japan

Scollay, Robert (2011), Trans Pacific Partnership: Challenges and Potential, paper presented at the Japan Society of International Economics 70th Anniversary Symposium, Kyoto, 11 June 2011

Wang, Min (2011), “The Domestic Political Economy of China's Preferential Trade Agreements" in Vinod K. Aggarwal and Seungjoo Lee (eds.) Trade Policy in the Asia-Pacific: The Role of Ideas, Interests, and Domestic Institutions, Springer, Germany

Yang, Jian (2009), "China's Competitive FTA Strategy: Realism on a Liberal Slide” in Mireya Solis, Barbara Stallings, and Saori N. Katada (eds.) Competitive 
Regionalism: FTA Diffusion in the Pacific Rim, Palgrave Macmillan, UK

\section{In Korean}

Ministry of Strategy and Finance (2009), FTA chu-jin-hyeon-hwang mich gi-dae-hyo-gwa [The Current State of FTA Promotion and the Anticipated Effects]

\section{Appendix: TPP and trade facilitation}

Here we would like show the policy implications of realization of TPP for international logistics. For that purpose, here we will summarize the chapter related to trade facilitation in the preceding version of TPP or the Trans-Pacific Strategic Economic Partnership Agreement (P4) which is already in effect.

In Chapter 5 Custom Procedures in P4, there are some contents which related to promotion of trade facilitation. It will provide direct effect for the efficiency of international logistics and improve productivity of logistics service sectors.

First of all, in Article 5.4 they emphasize to harmonize customs law systems to the rule and standards provided by World Customs Organization (WCO) as below.

\section{Article 5.4: Customs Procedures and Facilitation}

1. Customs procedures of the Parties shall, where possible and to the extent permitted by their respective customs law, conform with the standards and recommended practices of the World Customs Organization, including the principles of the International Convention on the Simplification and Harmonization of Customs Procedures.

2. Each Party shall ensure that its customs procedures and practices are predictable, consistent, transparent and facilitate trade.

3. The customs administrations of the Parties shall periodically review their customs procedures with a view to their further simplification and the development of further mutually beneficial arrangements to facilitate trade.

In Article 5.5, they mention cooperation by customs administrations by providing information as below. 


\section{Article 5.5: Customs Cooperation}

1. To the extent permitted by their domestic law, the customs administrations of the Parties may, as they deem fit, assist each other, in relation to originating goods, by providing information on the following:

(a) the implementation and operation of this Chapter;

(b) the movement of goods among the Parties;

(c) investigation and prevention of prima facie customs offences;

(d) developing and implementing customs best practice and risk management techniques;

(e) simplifying and expediting customs procedures;

(f) advancing technical skills and the use of technology;

(g) application of the Customs Valuation Agreement; and

(h) additional assistance in respect to other matters.

2. Where a Party providing information to another Party in accordance with this Chapter designates the information as confidential, the other Party shall maintain the confidentiality of the information.

In Article 5.7, they mention advance ruling, which means rules related customs must be informed in advance as below.

\section{Article 5.7: Advance Rulings}

1. Each Party, through its customs administration, shall provide in writing advance rulings in respect of the tariff classification and origin of goods and whether a good qualifies for entry free of customs duty in accordance with Article 3.5 (Goods Re-entered After Repair or Alteration) (hereinafter referred to as "advance rulings"), to a person described in Subparagraph 2(a).

2. Each Party shall adopt or maintain procedures for advance rulings, which shall:

(a) provide that an importer in its territory or an exporter or producer in the territory of another Party may apply for an advance ruling before the importation of goods in question;

(b) require that an applicant for an advance ruling provide a detailed description of the goods and all relevant information needed to issue an advance ruling;

(c) provide that its customs administration may, at any time during the course of issuing an advance ruling, request that the applicant provide additional information within a specified period;

(d) provide that any advance ruling be based on the facts and circumstances presented by the applicant, and any other relevant information in the possession of the 
decision-maker; and

(e) provide that an advance ruling be issued to the applicant expeditiously, or in any case within 60 days of the receipt of all necessary information.

3. A Party may reject requests for an advance ruling where the additional information requested by it in accordance with Subparagraph 2(c) is not provided within a specified time.

4. Subject to Paragraph 5, each Party shall apply an advance ruling to all importations of goods described in that ruling imported into its territory within

3 years of the date of that ruling, or such other period as required by that Party's laws.

5. A Party may modify or revoke an advance ruling upon a determination that the ruling was based on an error of fact or law, the information provided is false or inaccurate, if there is a change in domestic law consistent with this Agreement, or there is a change in a material fact, or circumstances on which the ruling is based.

6. Subject to the confidentiality requirements of a Party's domestic law, each Party shall publish its advance rulings.

7. Where an importer claims that the treatment accorded to an imported good should be governed by an advanced ruling, the customs administration may evaluate whether the facts and circumstances of the importation are consistent with the facts and circumstances upon which an advanced ruling was based.

8 The importing Party may apply measures as provided in Article 5.12.

In Article 5.8, they mention about administrative review and judicial review which is important to guarantee transparency of customs system as below.

\section{Article 5.8: Review and Appeal}

1. Each Party shall ensure that the importers in its territory have access to:

(a) administrative review independent of the official or office that issued the determination subject to review; and

(b) judicial review of the determination taken at the final level of administrative review, in accordance with the Party's domestic law. 
2. Notice of the decision on appeal shall be given to the appellant and the reasons for such decision shall be provided in writing.

3. The level of administrative review may include any authority supervising the customs administration.

In Article 5.10, they mention about paperless trading which is important to improve efficiency of logistics as below.

\section{Article 5.10: Paperless Trading}

1. The customs administrations shall each endeavor to provide an electronic environment that supports business transactions between it and its trading communities.

2. In implementing initiatives that provide for paperless trading, the customs administrations of the Parties shall take into account the methods developed in APEC and the World Customs Organization.

In Article 5.11, they mention about express consignments which is also important to improve efficiency of logistics as below.

\section{Article 5.11: Express Consignments}

Each Party shall ensure efficient clearance of all shipments, while maintaining appropriate control and customs selection. In the event that a Party's existing system does not ensure efficient clearance, it should adopt procedures to expedite express consignments to:

(a) provide for pre-arrival processing of information related to express consignments;

(b) permit the submission of a single document covering all goods contained in a shipment transported by the express shipment company through electronic means if possible; and

(c) minimize, to the extent possible, the documentation required for the release of express consignments.

As we mentioned above from contents of P4, coming TPP surely will include factors related trade facilitation. It is also possible some other contents will be introduced from member country's FTAs which include more advanced standards such as KORUS FTA. Therefore, TPP will provide substantial effect on international logistics service in Asia Pacific region. 